\title{
Temporal distribution in the abundance of the fiddler crab $U c a$ (Leptuca) uruguayensis Nobili, 1901 (Decapoda: Ocypodidae) from Garças River mangrove, Guaratuba Bay, southern Brazil
}

\author{
Salise Brandt Martins and Setuko Masunari
}

(SBM, SM) Department of Zoology, Institute of Biological Sciences, Federal University of Paraná. Centro Politécnico, Jardim das Américas, Caixa Postal 19020, 81531-980, Curitiba, Paraná, Brazil. E-mails: (SBM) salisebrandt@yahoo.com.br; (SM) setmas@ufpr.br

\begin{abstract}
A study on the temporal distribution, sex ratio, reproductive period, recruitment of juveniles and size composition of individuals of the fiddler crab Uca (Leptuca) uruguayensis was carried out in a population living in the Garças River mangrove, Guaratuba Bay, Paraná State, Brazil. Eight square samples of $0.25 \mathrm{~m}^{2}(0.50 \mathrm{~m}$ side) were obtained on a monthly basis, from April/2011 to March/2012. The crabs were collected through the excavation of burrows and their carapace width $(\mathrm{CW})$ was measured. Air and water temperatures varied from 19.0 to $29.5^{\circ} \mathrm{C}$ and 17.0 to $27.0^{\circ} \mathrm{C}$, respectively, the salinity from 7 to 23 and the soil temperature from 19.0 to $29.2^{\circ} \mathrm{C}$. A total of 1,099 fiddler crabs were collected, being 529 males, 520 females (of these, 9 ovigerous) and 50 sexually undifferentiated individuals. The average density of the population ranged from 12 (June/11) to 71 ind. $\mathrm{m}^{-2}$ (May/11), but its annual fluctuation was not correlated to abiotic variables. The sex ratio was 1:1 all year round and in all CW classes. Although in low abundance, ovigerous females were recorded in six months and juvenile crabs were present all year round, indicating a continuous reproduction and recruitment of the species. The CW of males ranged from 2.33 to $8.33 \mathrm{~mm}$ and that of females, from 2.52 to $7.79 \mathrm{~mm}$ : these data showed that this population is composed of smallest individuals among those studied.
\end{abstract}

Key words: Annual fluctuation, reproductive period, recruitment, sex ratio

\section{INTRODUCTION}

Uca (Leptuca) uruguayensis Nobili, 1901 is one of the ten species of fiddler crabs recorded in Brazil (Bezerra, 2012). It is distributed in Western Atlantic, from Rio de Janeiro (Brazil) to the mouth of the Quequén River in the province of Buenos Aires (Argentina) (Boschi, 2000). The species is associated with mangrove ecosystems in most of Brazilian coast of its distribution (Branco, 1991; Melo, 1996), or with estuarine marshes in the coast of southernmost Brazil, Uruguay and northern Argentina (Spivak et al., 1991).

Many aspects have been investigated on the populations of $U$. (L.) uruguayensis from different localities: abundance, distribution, population structure, fertility, life history, reproductive period, sex ratio and sexual maturity (Branco, 1991; Spivak et al., 1991; Oshiro et al., 1998; César et al., 2005, 2007; Costa et al., 2006; Bedê et al., 2008; Hirose et al., 2012). However, the population from Paraná State is still poorly known: only Masunari (2006) described the spatial distribution and abundance of this fiddler crab along a salinity gradient within the Guaratuba Bay, and Martins and Masunari (2013), the relative growth of a population living in the mangrove of the Garças River, within the mentioned bay. 
The population of $U$. (L.) uruguayensis living in the Guaratuba Bay, Paraná Sate, was the third most abundant with a maximum density of 84.0 specimens. $\mathrm{m}^{-2}$ in the collection site where the organic matter content was very high $(10.43 \%)$. It has euryhaline habit and occurred in almost all collection sites in this bay (Masunari, 2006). In the Garças River mangrove (Guaratuba Bay), these crabs occur mainly in sunny banks along streams that run inside it (Martins and Masunari, 2013).

This paper aims to describe the temporal oscillation of density and population structure of $U$. (L.) uruguayensis during a period of twelve months, in the Garças River mangrove, Guaratuba Bay, Paraná State, Brazil. The following aspects were treated: the annual fluctuation of density and sex ratio, reproductive period, recruitment of juveniles and the size composition of individuals.

\section{Material And Methods}

The study was conducted along the riverbank of

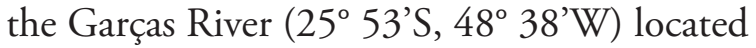
in the southern portion of the Guaratuba Bay, Paraná State, Brazil (Fig. 1). The area is dominated by relatively well preserved mangrove and it belongs to the Boguaçú State Park. For further details of the study area see Martins and Masunari (2013).

The collections were carried out monthly during spring low tides, from April/2011 to March/2012. Temperatures of the air, water and soil (at surface and depths of 15 and $25 \mathrm{~cm}$ ), and the water salinity were measured in each collection. The monthly average temperature and precipitation were provided by SIMEPAR, a weather station in the municipality of Guaratuba, Paraná State.

Monthly, crabs were collected from eight quadrats $\left(0.25 \mathrm{~m}^{2}\right)$ randomly placed within a $24 \mathrm{~m}^{2}$ soil surface of marginal sunny banks. All open burrows contained inside these quadrats were inspected and the crabs were manually collected with the aid of a small garden spade. The collected crabs were kept in plastic bags and transported in ice box to avoid losing appendages until arrival in the laboratory, where they were fixed in formalin and preserved in $75 \%$ ethanol for further analysis. In the laboratory, the crabs were identified, sexed, checked for the presence of eggs and the carapace width (CW) was measured between the antero-lateral angles with the aid of a digital microscope (DinoLite Pro AM-413T). These specimens were deposited in the Museum of Natural History of Capão da Imbuia (Curitiba, Parana State, Brazil), under No 3561 to 3651.

The density of crabs was expressed by the number of individuals per square meter $\left(\mathrm{n}^{\circ}\right.$. ind. $\mathrm{m}^{-2}$ ). The period of time when ovigerous females were found in the population was considered as the main breeding period. Those crabs without visible sexual dimorphism were considered as "sexually undifferentiated individuals" (SUI). Crabs SUI and those with less than $4.14 \mathrm{~mm} \mathrm{CW}$ for males and less than $3.52 \mathrm{~mm}$ CW for females were collectively

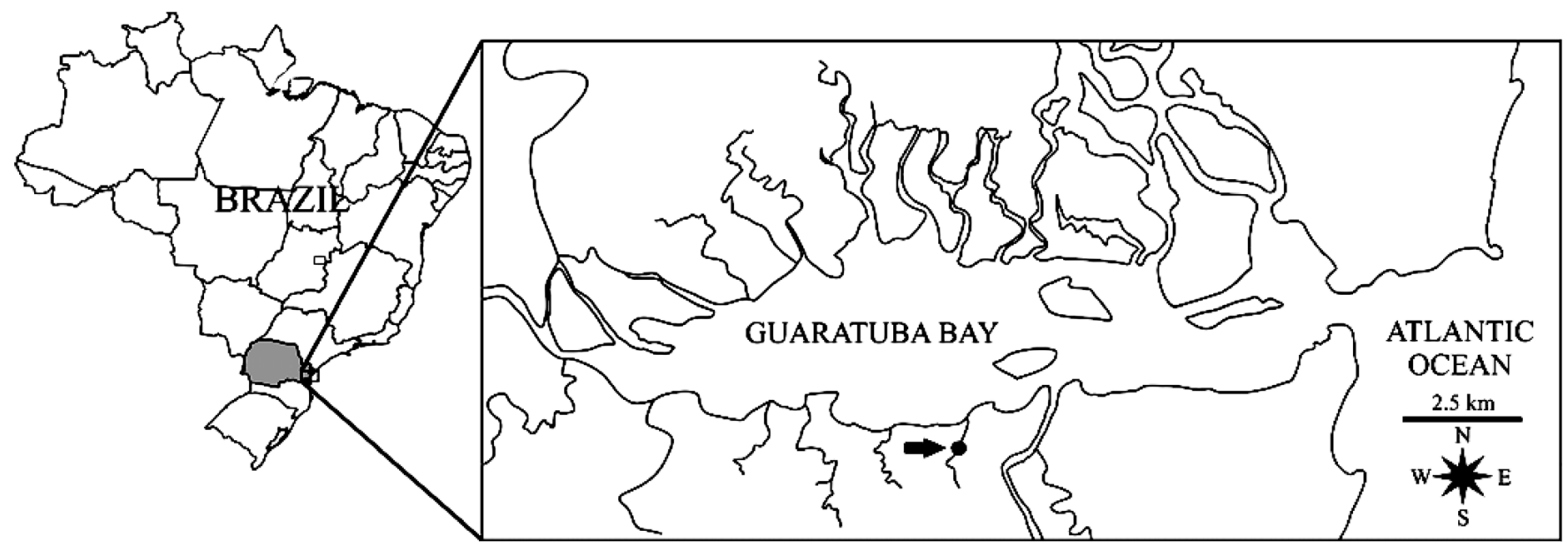

Figure 1. Map of Guaratuba Bay, Paraná State, Brazil. The black arrow indicates the study area in the Garças River mangrove. 
called juveniles, based on the study of relative growth of $U$. (L.) uruguayensis from the same collection site (Martins and Masunari, 2013).

The difference in the oscillation of the soil temperature at various depths was analyzed with unifactorial analysis of variance (ANOVA). The Spearman test was used to check for correlations between the density of the population of $U$. (L.) uruguayensis and the measured abiotic variables. The sex ratio was evaluated using the chi-square test $\left(c^{2}\right)$ for an expected proportion of $1: 1$, with a confidence level of $95 \%$. The differences in the absolute number of juveniles between the seasons were tested using Kruskal-Wallis. Mean size of males and females was compared using the MannWhitney test. The Shapiro-Wilk test was used to test the normality of frequency distributions (Zar, 1996).

\section{Results}

Air temperatures measured in the field ranged from 19.0 (July/11) to $29.5^{\circ} \mathrm{C}(\mathrm{March} / 12)$, and the monthly average temperatures fluctuated from 16.6 to $25.7^{\circ} \mathrm{C}$ (SIMEPAR) (Fig. 2), the water temperatures ranged from 17.0 (June/11) to $27.0^{\circ} \mathrm{C}(\mathrm{March} / 12)$, following the same pattern observed that the air temperatures, except May/11 and December/11, when the values were below the respective monthly average air temperatures (not shown in figure).

The temperatures of soil surface oscillated from 20.9 (September/11) to

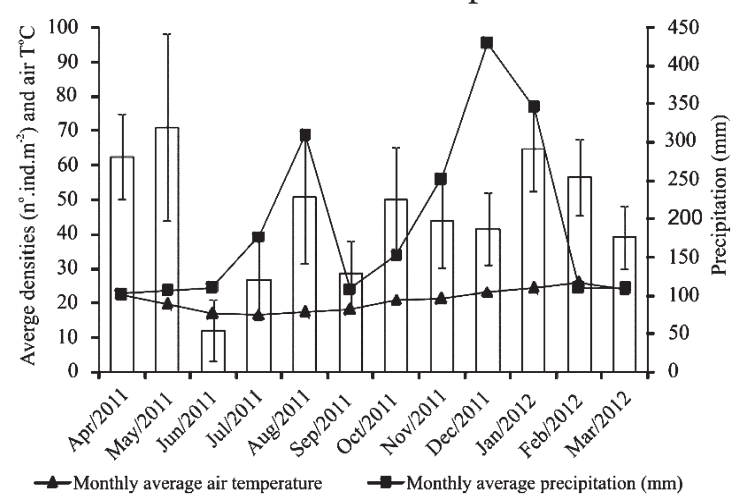

Figure 2. Uca (Leptuca) uruguayensis. Temporal oscillation of the monthly average densities $\left(\mathrm{n}^{\circ}\right.$.ind. $\mathrm{m}^{-2}$, solid bars) and standard deviations (vertical lines) of the population from the Garças River mangrove, during the collection period. The monthly average air temperature and precipitation are also shown. $29.2^{\circ} \mathrm{C}$ (February/12). Soil temperatures at 10 $\mathrm{cm}$ and $20 \mathrm{~cm}$ depth varied respectively from 19.0 (September/11) to $28.0^{\circ} \mathrm{C}$ (February/12) and 19.0 (September/11) to $27.9^{\circ} \mathrm{C}$. Soil temperatures did not differ significantly between the three depths ( $p>0.05)$. In general the soil temperatures (depth averages) followed the variation of air temperature (monthly averages).

The monthly rainfall ranged from 103.0 $\mathrm{mm}$ to $428.6 \mathrm{~mm}$ in the Guaratuba region (SIMEPAR) (Fig. 2), while the salinity of the river water fluctuated from 12 (August/11 and January/12) to 23 (June/11) in most months, but there was a sudden reduction in 7 (September/11 and October/11) and 9 (December/11), when a strong rainfall took place in the days before the collections. There was no correlation between salinity and monthly rainfall oscillations $\left(r^{2}=0.1921\right.$ and $\mathrm{p}>0.05)$.

\section{Temporal distribution in the abundance}

A total of 1,099 crabs were collected, of which 529 were males (152 juveniles and 377 matures), 520 females (101 juveniles, 410 matures and nine ovigerous) and 50 SUIs (Tab.1).

The average density of the population ranged from 12 ind. $\mathrm{m}^{-2}$ (June/11) to 71 ind. $\mathrm{m}^{-2}$ (May/11) (Fig. 2). This oscillation was not correlated with the yearly air temperatures $\left(\mathrm{r}^{2}=0.1828\right.$ and $\left.\mathrm{p}>0.05\right)$ nor with the precipitation fluctuation $\left(\mathrm{r}^{2}=0.3563\right.$ and $\mathrm{p}>$ 0.05) (Fig. 2).

\section{Sex ratio}

The overall sex ratio was $1: 1$ and did not differ significantly from the expected proportion $\left(\mathrm{c}^{2}\right.$ test $\left.=0.077, \mathrm{p}>0.05\right)$. The same sex ratio was found in all months (Fig. 3 and Tab. 1) and in all CW classes (Fig. 4).

\section{Reproductive and recruitment period}

A total of nine ovigerous females were collected in April/11 ( $\mathrm{n}=5)$, July/11 ( $\mathrm{n}=1)$, September/11 $(\mathrm{n}=1)$, October/11 $(\mathrm{n}=1)$ and March/12 ( $=1$ ) (Fig. 5). 


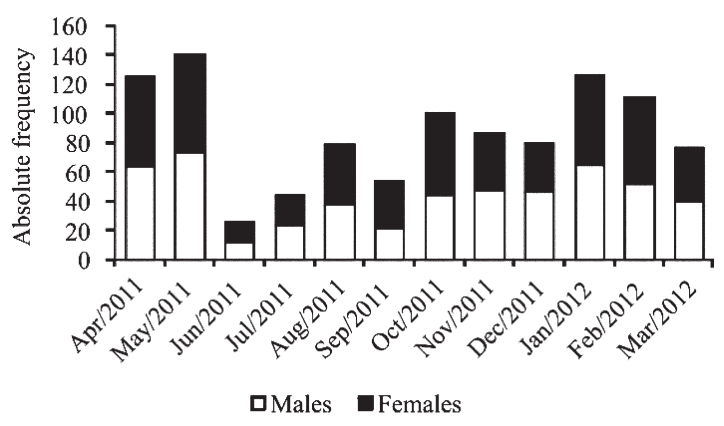

Figure 3. Uca (Leptuca) uruguayensis. Absolute number of sexually adult males and females during the collection months. The sex ratio was 1:1 all year round.

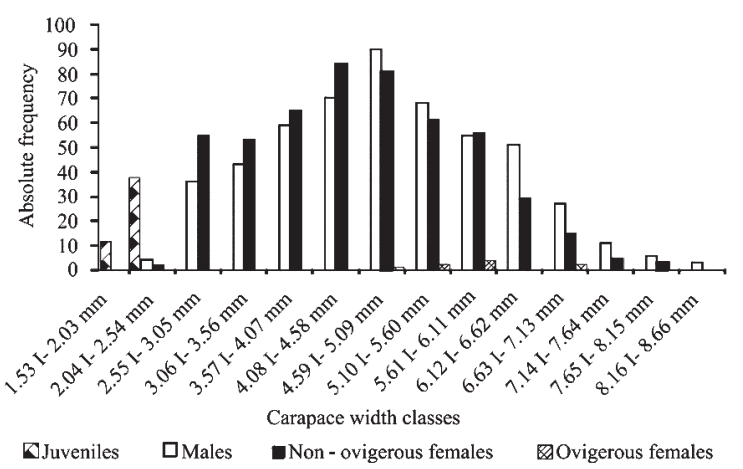

Figure 4. Uca (Leptuca) uruguayensis. Absolute frequency distribution of the demographic categories (SUIs, males, nonovigerous females and ovigerous females) into carapace width classes during the study period.

Table 1. Uca (Leptuca) uruguayensis. Absolute number of males and females during the months of study in the Garças River mangrove. The monthly sex ratios have no statistical difference from the expected 1:1. The demographic category SUI was excluded from this analysis.

\begin{tabular}{lccccc}
\hline Month & Males & Females & $\begin{array}{c}\text { Sex } \\
\text { ratio }\end{array}$ & $\chi^{2}$ & $\mathrm{p}$ \\
\hline April/11 & 64 & 61 & $1.04: 1$ & 0.072 & 0.8580 \\
May/11 & 73 & 67 & $1.08: 1$ & 0.257 & 0.6726 \\
June/11 & 12 & 14 & $0.85: 1$ & 0.154 & 0.8445 \\
July/11 & 24 & 20 & $1.2: 1$ & 0.364 & 0.6511 \\
August/11 & 38 & 41 & $0.92: 1$ & 0.114 & 0.8220 \\
September/11 & 22 & 32 & $0.68: 1$ & 1.852 & 0.2207 \\
October/11 & 44 & 56 & $0.78: 1$ & 1.44 & 0.2713 \\
November/11 & 48 & 39 & $1.23: 1$ & 0.931 & 0.3911 \\
December/11 & 47 & 33 & $1.42: 1$ & 2.45 & 0.1461 \\
January/12 & 65 & 61 & $1.06: 1$ & 0.127 & 0.7893 \\
February/12 & 52 & 59 & $0.88: 1$ & 0.441 & 0.5690 \\
March/12 & 40 & 37 & $1.08: 1$ & 0.117 & 0.8197 \\
Total & 529 & 520 & $1.01: 1$ & 0.077 & 0.8049 \\
\hline
\end{tabular}

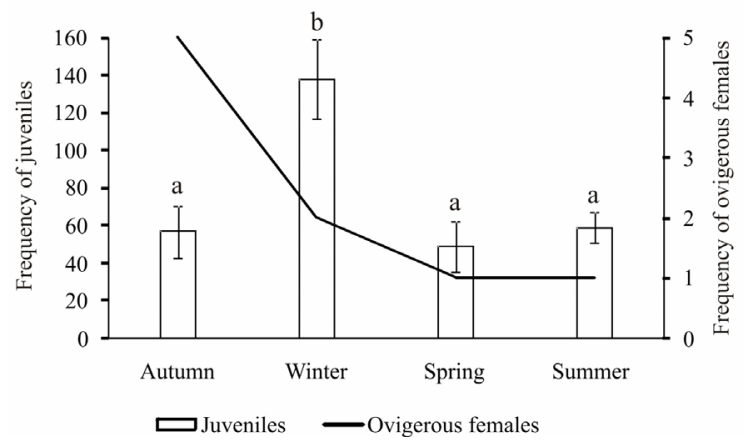

Figure 5. Uca (Leptuca) uruguayensis. Absolute frequencies of juveniles (bar) and ovigerous females (line) at the Garças River mangrove. Equal letters indicate that there is no statistical difference among data. Juveniles = SUIs + sexually immature individuals.

The juveniles were present in all sampled months indicating a continuous recruitment, with higher abundance in winter (July, August and September, $\mathrm{n}=138$ ) followed by summer (January, February and March, $\mathrm{n}=59$ ), autumn (April, May and June, $\mathrm{n}=57$ ) and spring (October, November and December, $\mathrm{n}=49$ ). The highest frequency of ovigerous females recorded in autumn was followed by the season of highest frequency of juveniles (winter) (Fig. 5). There was a statistically significant difference in the frequency of juveniles between winter and summer (Kruskal-Wallis; $\mathrm{H}=11.0578 ; \mathrm{p}$ $<0.05$ ), winter and spring (Kruskal-Wallis; $\mathrm{H}$ $=11.0578 ; \mathrm{p}<0.05)$ and winter and autumn (Kruskal-Wallis; $\mathrm{H}=10.6936$; $\mathrm{p}<0.05$ ), but a continuous recruitment throughout the year is evident (Fig. 5).

\section{Population structure in carapace width classes}

The size frequency distribution was studied by grouping the crabs into $0.50 \mathrm{~mm}$ CW intervals: (1) 1.53 to $2.03 \mathrm{~mm}$; (2) 2.04 to $2.54 \mathrm{~mm}$; (3) 2.55 to $3.05 \mathrm{~mm}$; (4) 3.06 to $3.56 \mathrm{~mm}$; (5) 3.57 to $4.07 \mathrm{~mm}$; (6) 4.08 to $4.58 \mathrm{~mm}$; (7) 4.59 to $5.09 \mathrm{~mm}$; (8) 5.10 to $5.60 \mathrm{~mm}$; (9) 5.61 to $6.11 \mathrm{~mm}$; (10) 6.12 to $6.62 \mathrm{~mm}$; (11) 6.63 to $7.13 \mathrm{~mm}$; (12) 7.14 to $7.64 \mathrm{~mm}$; (13) 7.65 to $8.15 \mathrm{~mm}$ and (14) 8.16 to $8.66 \mathrm{~mm}$.

Males and non-ovigerous females were recorded in all CW classes, except for 1.53 to $2.03 \mathrm{~mm}$ class which was occupied exclusively by SUIs. This last demographic category was also present in the 2.04 to $2.54 \mathrm{~mm}$ class. 
Additionally, only a male was found in the last class ( 8.16 to $8.66 \mathrm{~mm}$ ). Non-ovigerous females predominated slightly in six CW classes, mainly in the smaller ones, while males in the longer ones; however without statistical significance. Ovigerous females occurred in four classes from 4.59 to $7.13 \mathrm{~mm}$. The CW frequency distribution of the population was unimodal, both for males (Shapiro-Wilk = 0.9378, p > 0.05) and females (Shapiro-Wilk $=0.9275, \mathrm{p}>0.05)$.

Males' CW ranged from 2.33 to 8.33 $\mathrm{mm}(4.89 \pm 1.23 \mathrm{~mm})$, while the nonovigerous females' from 2.52 to $7.79 \mathrm{~mm}$ $(4.60 \pm 1.17 \mathrm{~mm})$, the ovigerous females' from 5.05 to $6.95 \mathrm{~mm}(5.84 \pm 0.63 \mathrm{~mm})$, and the SUIs from 1.65 to $2.50 \mathrm{~mm}(2.17$ $\pm 0.26 \mathrm{~mm})$. Males were significantly bigger than non-ovigerous females $(4.60 \mathrm{~mm} \pm 1.17)$ (Mann-Whitney $=3.8766, \mathrm{p}<0.05$ ), but did not differ significantly from ovigerous females (Mann-Whitney $=2.5140 ; \mathrm{p}>0.05)$.

\section{DisCUSSION}

\section{Temporal distribution in the density}

The oscillation of the average density of the population was not related to the abiotic variables' in the present study. However, the lowest density occurred in the winter, in the month (June) of lowest water temperature $\left(17^{\circ} \mathrm{C}\right)$ and the second lowest average air temperature $\left(16.9^{\circ} \mathrm{C}\right)$.

Likewise, in Mar Chiquita, Argentina (Spivak et al., 1991) the abundance of $U$. (L.) uruguayensis was not related to air/ water temperatures: the highest (August, $\approx$ 40 ind. $\mathrm{m}^{-2}$ ) and lowest (April, $\approx 4$ ind. $\mathrm{m}^{-2}$ ) densities occurred in different months from the present study (71 ind. $\mathrm{m}^{-2}$ in May and 12 ind. $\mathrm{m}^{-2}$ in June). Later, César et al. (2005) obtained the maximum density in February ( 42 ind. $\left.\mathrm{m}^{-2}\right)$ and the minimum in July $\left(0\right.$ ind. $\left.\mathrm{m}^{-2}\right)$ for the population from Samborombón Bay, Argentina, showing a significant correlation with water temperature and salinity oscillations: the higher densities were recorded in spring and summer while the smaller ones in the colder seasons (autumn and winter).
This pattern was also observed by Branco (1991) in the mangroves of Itacorubi (Santa Catarina State), Brazil, where the maximum abundance was recorded in spring, $(\mathrm{n}=270)$ and the minimum in winter, $(\mathrm{n}=25)$. Anyway, it seems that $U$. (L.) uruguayensis reduces its activities during cold months in regions with marked oscillation of air temperature, resulting in low densities in cold months, in spite of different methodologies of collection of crabs: by excavation performed by Spivak et al. (1991), by capture of crabs walking on the surface by Branco (1991), or by inspection of burrows (present study).

The lack of relationship between the oscillation of density and that of temperatures highlights the eurythermic nature of $U$. (L.) uruguayensis, that could stand a $10.5^{\circ} \mathrm{C}$ range of average monthly temperatures (from 19.0 to $29.5^{\circ} \mathrm{C}$ ). Within this oscillation range of average air temperature, most of these crabs in Guaratuba Bay, are able to opening burrows throughout the year.

In contrast, the abundance of $U$. (L.) uruguayensis from Samborombón Bay, Argentina, showed a significant correlation with water temperature and salinity, higher densities being recorded in the warmer season and higher water salinities, while the lowest ones in colder seasons and low salinities (César et al., 2005). Another difference in the population parameter was the density: while in the population of Argentina, it varied from $0-42$ ind. $\mathrm{m}^{-2}$, in the present study, it ranged from $12-71$ ind. $\mathrm{m}^{-2}$. This difference may be connected to the contrasting size of these crabs: the male crabs of Argentina population measure up to $14.47 \mathrm{~mm} \mathrm{CW}$ (Spivak et al., 1991), while those of the Guaratuba Bay, 8.33 mm CW (Martins and Masunari, 2013).

The euryhaline nature of $U_{c a}(L$. uruguayensis observed in the present study (it stands salinity range of 16 , from 7 to 23) is in accordance to Masunari (2006) for other populations from the same estuarine area, where salinities varied from 7.92 to 23.64. However, these salinity ranges are quite narrow if compared to $U_{c a}$ (Minuca) longisignalis Salmon and Atsaides, 1968 and Uca (Minuca) 
subcylindrica Stimpson, 1859 from the semiarid regions of Texas, USA: they support salinity variations in the laboratory from 2.0 to 90.0 and 0.08 to 110.0 , respectively (Rabalais and Cameron, 1985).

\section{Sex ratio}

The sex ratio found in this study $(1: 1)$ is in accordance with César et al. (2005) with the population from Samborombón Bay, Argentina, but different from that found by Bedê et al. (2008) in the mangrove of Itacuruçá, Brazil (1:0.42) and from Mar Chiquita, Argentina (1:1.68) (Spivak et al., 1991).

According to Genoni (1985), the sex ratio among populations of $U c a$ spp. is often different from 1:1, males being usually more abundant than females. However, there are several Brazilian populations of $U c a$ with sex ratio of $1: 1$; for instance $U c a$ (Minuca) thayeri Rathbun, 1900 and Uca (Leptuca) leptodactyla Rathbun, 1898 studied by Bezerra and Mathews-Cascon (2006 and 2007, respectively), Uca (Minuca) rapax Smith, 1870 by Castiglioni et al. (2006), Uca (Uca) maracoani Latreille, 1802-1803 by Hirose and Negreiros-Fransozo (2008) and by $\mathrm{Di}$ Benedetto and Masunari (2009) and Uca (Minuca) mordax (Smith, 1870) by Fransozo et al. (2009).

Valiela et al. (1974) and Emmerson (1994) reported that the deviation of sex ratio from 1:1 seems to be related to the reproductive system of fiddler crabs: because males spend more time on the surface defending territory and performing waving to attract females, they are more visible and therefore more susceptible to predation. This assumption can explain the sex ratio in populations where females are prevalent, as in Uca (Minuca) pugilator Bosc, 1802, Uca (Leptuca) cumulanta Crane, 1943 and $U$. (M.) rapax Smith, 1870 (Colby and Fonseca, 1984; Koch et al., 2005). Additionally, Souza and Fontoura (1993) suggested another possible event: easier catch of females.

Other factors may also cause deviations in the expected sex ratio as the differences in the food availability for females and males, habitat fragmentation, spatial use of resources and differential migration patterns (Wilson and Pianka, 1963; Giesel 1972; Wolf et al., 1975; Christy and Salmon, 1984; Montague, 1980; Genoni, 1985; Spivak et al., 1991; Costa and Negreiros-Fransozo, 2002).

The mendelian sex ratio observed in the population of $U$. (L.) uruguayensis from the Garças River mangrove may indicate that males and females are under similar conditions (e.g. food availability, predation pressure).

\section{Reproductive period and recruitment}

The low frequency of ovigerous females recorded in this study probably was due to their reclusive habit for protecting themselves against unsuitable conditions. This inference is supported by the general behavior of the ovigerous females of large front fiddler crabs, to which $U$. (L.) uruguayensis belongs, that they stop feeding and incubate their eggs inside the burrows (Crane, 1975; Murai et al., 1987; Christy and Salmon, 1991). Actually, Costa et al. (2006) observed ovigerous females of this species living in deep burrows, confirming the statement of the above authors. This strategy is perceived in order to protect the egg mass against extreme environmental conditions, enabling a synchronism on the embryonic development and larval hatching (Salmon, 1987).

Although in very small frequency, ovigerous females were present in all seasons at the Guaratuba Bay as observed at Fortaleza Bay, São Paulo State, Brazil by Costa et al. (2006). These data may suggest that $U$. (L.) uruguayensis has continuous reproduction at least for populations living in latitudes lower than Paraná State, Brazil. On the other hand, in the studies carried out by César et al. (2007) in the Samborombón Bay and by Spivak et al. (1991) in Mar Chiquita, in temperate climate in Argentina, it was observed that reproduction is seasonal (spring and summer).

The higher number of juveniles in the winter months of the present study could be produced by ovigerous females that were more numerous in Autumn months (Fig. 5), in spite of the low frequency of these females. This assumption is based on the observation 
of Costa and Negreiros-Fransozo (2002) with population of $U$. (M.) thayeri from São Paulo State coast, and of Castiglioni et al. (2006) with population of $U$. (M.) rapax from Rio de Janeiro State, both in Brazil.

\section{Population structure in carapace width}

The slight predominance of females (without statistical differences in the number of males and females) in the smaller CW classes and of males in the larger ones of the present study may be explained by differential growth in males and females. These females have two main events that may slow or stop their somatic growth: part of their energy is directed to gonadal development and for the supply during egg laying (Warner, 1967; Díaz and Conde, 1989; Johnson, 2003) and they hardly feed during the egg incubation (Crane, 1975; Christy and Salmon, 1991). On the other hand, males can grow continuously attaining larger size for courtship purposes (Warner, 1967; Adiyodi and Adiyodi, 1970; Wenner, 1972; Christy and Salmon, 1984; Díaz and Conde, 1989; Henmi and Kaneto, 1989). This observation was also reported by Bedê et al. (2008) in the population of $U$. (L.) uruguayensis from Rio de Janeiro State coast. As mentioned above, males and females of $U$. (L.) uruguayensis from the Guaratuba Bay are under the same predation pressure, unlike other Uca species (Ribeiro et al., 2003).

The unimodal distribution of CW classes for both sexes in the present study was different from the population of Rio de Janeiro State coast where a bimodal distribution for females was recorded (modal CW classes in 5.0 to 6.0 $\mathrm{mm}$ and in 7.0 to $8.0 \mathrm{~mm}$ ) (Bedê et al., 2008). These authors explained this exceptional feature as a consequence of the small number of female samples $(n=24)$.

The size frequency distribution of a population is a dynamic feature that can change throughout the year as a result of the reproduction and juvenile recruitment (Thurman, 1985). The unimodal distribution observed in the present study suggests a stable population, with continuous and constant recruitment and mortality rates throughout the life cycle, a pattern common to other species of $U_{c a}$, mainly of tropical regions (Díaz and Conde, 1989; Litulo, 2004; 2005).

The CW values for both sexes obtained in the present study are noteworthy for their smallness. The population of the Guaratuba Bay is composed of the smallest individuals (males 2.33 to $8.33 \mathrm{~mm}$, non-ovigerous females 2.52 to $7.79 \mathrm{~mm}$ and ovigerous females 5.05 to $6.95 \mathrm{~mm}$ ). The population from Itacuruçá mangrove, Rio de Janeiro, measured 4.57 to $12.00 \mathrm{~mm}$ (males) and 5.00 to $10.86 \mathrm{~mm}$ (females) (Bedê et al., 2008), from Indaiá River mangrove, São Paulo, measured from 4.18 to $11.60 \mathrm{~mm}$ (males) and 3.90 to $9.80 \mathrm{~mm}$ (females) (Hirose et al., 2012), and from Argentina, maximum CW values measured were $14.47 \mathrm{~mm}$ (males) and $13.43 \mathrm{~mm}$ (females) (Spivak et al., 1991) and $14.10 \mathrm{~mm}$ (males) and $12.00 \mathrm{~mm}$ (females) (Hirose et al., 2012). Differences in food availability seem to be the main cause for this strong CW discrepancy among populations from different localities (Colpo and NegreirosFransozo, 2004). Future investigations would confirm this hypothesis.

Despite the small size of the individuals that compose the population of $U$. (L.) uruguayensis at the Garças River mangrove, there are indications that it is well established as pointed out by the presence of all demographic categories throughout the year especially of ovigerous females and juveniles.

Acknowledgements - We are grateful to Prof. Dr. Luis Ernesto Arruda Bezerra from Universidade Federal Rural do Semi-Árido (UFERSA) for the confirmation of identification of $U_{c a}(L$.$) uruguayensis, to Prof.$ Dr. Luís Amilton Foerster from Federal University of Paraná for the English revision, to the Director of the meteorological system of Paraná (SIMEPAR) for temperature and rainfall data, and to MSc. Thaís Fernanda Moreto for her help in the field work. All biological sampling of the present study complies with the current laws of Paraná State and Brazilian Federal Government, and was conducted with the permission of SISBIO (Authorization system and information on biodiversity license No. 29567-1). This is Contribution No. 1899 of Zoology Department, Federal University of Paraná. 


\section{REFERENCES}

Adiyodi, K.G. and Adiyodi R.G. 1970. Endocrine control of reproduction Decapoda Crustacea. Biological Review, 45: 121-165.

Bedê, L.M.; Oshiro, L.M.Y.; Mendes, L.M.D. and Silva, A.A. 2008. Comparaçáo da estrutura populacional das espécies de Uca (Crustacea: Decapoda: Ocypodidae) no Manguezal de Itacuruçá, Rio de Janeiro, Brasil. Revista Brasileira de Zoologia, 25(4): 601-607.

Bezerra, L.E.A. 2012. The fiddler crabs (Crustacea: Brachyura: Ocypodidae: genus $U_{c a}$ ) of the South Atlantic Ocean. Nauplius, 20(2): 203-246.

Bezerra, L.E.A. and Matthews-Cascon, H. 2006. Population structure of the fiddler crab Uca leptodactyla Rathbun, 1898 (Brachyura: Ocypodidae) in a tropical mangrove of northeast Brazil. Thalassas, 22(1): 65-75.

Bezerra, L.E.A. and Matthews-Cascon, H. 2007. Population and reproductive biology of the fiddler crab Uca thayeri Rathbun, 1900 (Crustacea: Ocypodidae) in a tropical mangrove from Northeast Brazil. Acta Oecologica, 31(3): 251-258.

Boschi, E.E. 2000. Species of decapod crustaceans and their distribution in the American marine zoogeographic provinces. Revista de Investigación y Desarrollo Pesquero, 13: 7- 136.

Branco, J.O. 1991. Aspectos ecológicos dos Brachyura (Crustacea: Decapoda) no manguezal do Itacorubi, SC, Brasil. Revista Brasileira de Zoologia, 7(1-2): 165-179.

Castiglioni, D.S.; Negreiros-Fransozo, M.L. and Mortari, R.C. 2006. Biologia populacional do caranguejo violinista Uca rapax (Smith, 1870) (Crustacea, Ocypodidae), proveniente de uma área de manguezal degradado em Paraty, RJ, Brasil. Atlântica, 28(2): 73-86.

César, I.I.; Armendariz, L.C. and Becerra, R.V. 2005. Bioecology of the fiddler crab Uca uruguayensis and the burrowing crab Chasmagnathus granulatus (Decapoda, Brachyura) in the Refugio de Vida Silvestre, Bahía Samborombón, Argentina. Hydrobiologia, 545(1), 237-248.

César, I.I.; Armendáriz, L.C. and Becerra, R.V. 2007. Fecundity of Uca uruguayensis and Chasmagnathus granulatus (Decapoda, Brachyura) from the "Refúgio de Vida Silvestre", Bahía Samborombón, Argentina. Brazilian Journal of Biology, 67(4): 749-753.

Christy, J.H. and Salmon, M. 1984. Ecology and evolution of mating systems of fiddler crabs (genus Uca). Biological Review, 59: 483-509.

Christy, J.H. and Salmon, M. 1991. Comparative studies of reproductive behavior in mantis shrimps and fiddler crabs. American Zoologist, 31(2): 329337.

Colby, D.R. and Fonseca, M.S. 1984. Population dynamics, spatial dispersion and somatic growth of the sand fiddler crab Uca pugilator. Marine Ecology Progress Series, 16: 269-279.

Colpo, K.D. and Negreiros-Fransozo, M.L. 2004. Comparison of the population structure of the fiddler crab Uca vocator (Herbst, 1804) from three subtropical mangrove forests. Scientia Marina, 68(1): 139-146.

Costa, T.M. and Negreiros-Fransozo, M.L. 2002. Population biology of Uca thayeri Rathbun, 1900 (Brachyura, Ocypodidae) in a subtropical South American mangrove area: results from transect and catch-per-unit-effort techniques. Crustaceana, 75(10): 1201-1218.
Costa, T.M.; Silva, S.M.J. and Negreiros-Fransozo, M.L. 2006. Reproductive pattern comparison of Uca thayeri Rathbun, 1900 and Uca uruguayensis Nobili, 1901 (Crustacea, Decapoda, Ocypodidae). Brazilian Archives of Biology and Technology, 49(1): 117-123.

Crane, J. 1975. Fiddlers crabs of the world (Ocypodidade: Genus $U c a$ ). Princeton University, Princeton, 736p.

Di Benedetto, M. and Masunari, S. 2009. Estrutura populacional de Uca maracoani (Decapoda, Brachyura, Ocypodidae) no Baixio Mirim, Baía de Guaratuba, Paraná. Iheringia, Serie Zoologia 99(4): 381-389.

Díaz, H. and Conde, J.E. 1989. Population dynamics and life history of the mangrove crab Aratus pisonii (Brachyura, Grapsidae) in a marine environment. Bulletin of Marine Science, 45(1): 148-163.

Emmerson, W.D. 1994. Seasonal breeding cycles and sex ratio of eight species of crabs from Magazana, a mangrove estuary in Transkei, southern Africa. Journal of Crustacean Biology, 14(3): 568-578.

Fransozo, V.; Mortari, R.C. and Benetti, A.S. 2009. Population biology of Uca mordax (Smith, 1870) (Crustacea, Decapoda, Ocypodidae) from the southeastern coast of Brazil. Estudos de Biologia, 31(73/74/75): 23-31.

Genoni, G.P. 1985. Food limitation in salt marsh fiddler crabs Uca rapax (Smith) (Decapoda: Ocypodidae). Journal of Experimental Marine Biology and Ecology, 87: 97-110.

Giesel, J.T. 1972. Sex ratio, rate of evolution, and environmental heterogeneity. American Naturalist, 949(106): 380-387.

Henmi, Y. and Kaneto, M. 1989. Reproductive Ecology of Three Ocypodid Crabs. 1. The Influence of Activity Differences on Reproductive. Ecological Research, 4: 17-29.

Hirose, G.L; Fransozo, V.; Tropea, C.; López-Greco, L.S. and Negreiros-Fransozo, M.L. 2012. Comparison of body size, relative growth and size at onset maturity of Uca uruguayensis (Crustacea, Decapoda: Ocypodidae) from different latitudes in the southwestern Atlantic. Journal of the Marine Biological Association of the United Kingdom, 93: 781-788.

Hirose, G.L. and Negreiros-Fransozo, M.L. 2008. Population biology of $U_{c a}$ maracoani Latreille 18021803 (Crustacea, Brachyura, Ocypodidae) on the southeastern coast of Brazil. Pan-American Journal of Aquatic Sciences, 3: 373-383.

Johnson, P.T.J. 2003. Biased sex ratios in fiddler crabs (Brachyura, Ocypodidae): A review and evaluation of the influence of sampling method, size class, and sex-specific mortality. Crustaceana, 76: 559-580.

Koch, V.; Wolff, M. and Diele, K. 2005. Comparative population dynamics of four fiddler crabs (Ocypodidae, genus Uca) from a North Brazilian mangrove ecosystem. Marine Ecology Progress Series, 291: 177-188.

Litulo, C. 2004. Fecundity of the pantropical fiddler Crab Uca anuulipes ( $\mathrm{H}$. Milne Edwards, 1837) (Brachyura: Ocypodidae) at Costa do sol Mangrove, Maputo Bay, southern Mozambique. Western Indian Ocean Journal Marine Science, 3(1): 87-91.

Litulo, C. 2005. Population biology of the fiddler crab Uca annulipes (Brachyura: Ocypodidae) in a tropical East Africa mangrove (Mozambique). Estuarine Coastal Marine Science, 62: 283-290. 
Martins, S.B. and Masunari, S. 2013. Relative growth in the fiddler crab Uca uruguayensis Nobili, 1901 (Crustacea, Decapoda, Ocypodidae) from Garças River mangrove, Guaratuba Bay, southern Brazil. Nauplius, 21(1): 35-41.

Masunari, S. 2006. Distribuição e abundância dos caranguejos Uca Leach (Crustacea, Decapoda, Ocypodidae) na Baía de Guaratuba, Paraná, Brasil. Revista Brasileira de Zoologia, 23(4): 901-14.

Melo, G.A.S. 1996. Manual de identificação dos Brachyura (caranguejos e siris) do litoral brasileiro. Plêiade/FAPESP, São Paulo, 604p.

Montague, C.L. 1980. A natural history of temperate western Atlantic fiddler crabs (Genus $U_{c a}$ ) with reference to their impact on the salt marsh. Contributions in Marine Science, 23: 25-55.

Murai, M.; Goshima, S. and Henmi, Y. 1987. Analysis of the mating system of the fiddler crab, Uca lactea. Animal Behavior, 35: 1334-1342.

Oshiro, L.MY.; Silva, R. and Silva, Z.S. 1998. Composição da fauna de braquiúros (Crustacea, Decapoda) dos manguezais da Baía de Sepetiba, RJ. Nauplius, 6: 31-40.

Rabalais, N.N. and Cameron, J.N. 1985. The effects of factors important in semi-arid environments on the early development of Uca subcylindrica. The Biological Bulletin, 168(1): 147-160.

Ribeiro, P.D.; Iribarne, O.O.; Jaureguy, L.; Navarro, D. and Bogazzi, E. 2003. Variable sex-specific mortality due to shorebird predation on a fiddler crab. Canadian Journal of Zoology, 81: 1209-1221.

Salmon, M. 1987. On the reproductive behavior of the fiddler crab Uca thayeri, with comparisons to $U$. pugilator and $U$. vocans: evidence for behavioral convergence. Journal of Crustacean Biology, 7(1): 2544.

Souza, G.D. and Fontoura, N.F. 1993. Estrutura populacional e fecundidade de Pachygrapsus transversus (Saussure, 1858), no mole do rio Tramandaí, Rio Grande do Sul, Brasil (Crustacea, Decapoda, Grapsidae). Comunicaçóes do Museu de Ciências e Tecnologia, 52: 29-37.

Spivak, E.D.; Gavio, M.A. and Navarro, C.E. 1991. Life history and structure of the world's southernmost Uca populations: Uca uruguayensis (Crustacea: Brachyura) in Mar Chiquita lagoon (Argentina). Bulletin of Marine Science, 48: 679-688.

Thurman, C.L. 1985. Reproductive biology and population structure of the fiddler crab $U c a$ subcylindrica (Stimpson). Biological Bulletin, 169: 215-229.

Valiela, J.M.; Babiec, D.E.; Atherton, W.; Seitzinger, S. and Krebs, C. 1974. Some consequences of sexual dimorfism: feeding in male and female fiddler crabs Uca pugnax (Smith). Biological Bulletin, 147: 652660.

Warner, G.F. 1967. The life history of mangrove tree crab, Aratus pisonii. Journal of Zoology, 153: 321335.

Wenner, A.M. 1972. Sex-ratio as a function of size in marine Crustacea. American Naturalist, 106: 321 350.

Wilson, M.F. and Pianka, E.R. 1963. Sexual selection, sex ratio and mating system. American Naturalist, 97: 405-407.

Wolf, P.; Shanholtaer, S.F. and Reimold, R.J. 1975. Population estimates for Uca pugnax on Duplin estuary marsh. Georgia, USA. Crustaceana, 29: 7991.
Zar, J.H. 1996. Biostatistical analysis. Prentice-Hall, Upper Sadle River, 662p. 